\title{
The effect of testosterone supplementation on morphometry and VEGF expression level of thoracic aorta in aged mice
}

\author{
İlknur DABANOĞLU, Mehmet Utkan ÖREN
}

Adnan Menderes University, Faculty of Veterinary Medicine, Department of Anatomy, Aydın, Turkey.

\begin{abstract}
Summary: The aim of this study was to determine the effects of the testosterone hormone level on morphometry and vascular endothelial growth factor (VEGF) expression level of thoracic aorta of aged mice using histological and molecular techniques. A total of 30 aged mice ( 15 males and 15 females) were enrolled in 3 study groups: sham operation group (Control), gonadectomy group (G) and gonadectomy and testosterone supplementation group (GTS). Serum testosterone levels were measured by ELISA. Intima and media thickness and inner diameter of thoracic aorta were measured by morphometric investigation. The levels of the angiogenic factor, VEGF (vascular endothelial growth factor) mRNA in thoracic aorta were determined by RT-PCR. Although the alterations in the level of testosterone had no significant effects on intima or media thickness of the male thoracic aorta, in female, there was a significant increase $(\mathrm{p}<0.01)$ on intimal thickness in thoracic aorta following gonadectomy and hormone supplementation. The largest inner diameter was in testosterone supplementation groups of both sexes. Gonadectomie operation caused decrease in VEGF mRNA levels of thoracic aorta in male $(\mathrm{p}<0.05)$ and female mice. Interestingly, testosterone replacement caused an important decrease $(\mathrm{p}<0.01)$ in the expression of VEGF of aorta in female whereas resulted with an increase in male. Present results showed that testosterone hormone had different angiogenic effects on thoracic aorta in male and female aged mice. Additionally, gonadectomie operation in aged mice caused decrease in the level of VEGF mRNA levels in both sexes.
\end{abstract}

Keywords: Aged, mice, testosterone, thoracic aorta, VEGF.

\section{Yaşlı farelerde testosteron takviyesinin aorta thoracica'nın morfometri ve VEGF ekspresyon seviyesi üzerine etkisi}

Özet: Çalışmanın amacı, yaşlı farelerde testosteron hormonu seviyesinin aorta thoracica'daki anjiogenik etkisini ve vaskülo endoteliyal büyüme faktörünün (VEGF) ekspresyon düzeyini histolojik ve moleküler yöntemlerle belirlemektir. Çalışmada 30 adet yaşlı fare (15 erkek ve 15 dişi) üç farklı gruba ayrıldı. Bu gruplar; yalancı gonadektomi operasyonu yapılan kontrol grubu, gonadektomi operasyonu yapılan (G) grup ve hem gonadektomi hem de testosteron takviyesi yapılan (GTS) gruptur. Hayvanların kanındaki testosteron seviyesi ELISA testi ile ölçüldü. Aorta thoracica'nın intima ve media kalınlıkları ile iç çapı morfometrik incelemelerle belirlendi. Aorta thoracica'daki anjiogenik faktörlerden biri olan VEGF mRNA miktarı ise RT-PCR tekniği ile tespit edildi. Testosteron seviyesindeki değişimlerin erkeklerde aorta thoracica'nın intima ve media kalınlıklarında önemli bir etkisinin olmadığı saptandı. Dişilerde ise gonadektomi operasyonundan sonra yapılan hormon takviyesinin intima kalınlığında bir artışa $(p<0.01)$ neden olduğu belirlendi. Aorta thoracica'nın iç çapı en geniş olarak her iki cinste de GTS grubunda belirlendi. Gonadektomi operasyonunun VEGF mRNA miktarı üzerinde erkek $(\mathrm{p}<0.05)$ ve dişilerde bir azalmaya neden olduğu saptandı. Testosteron takviyesi aorta thoracica'daki VEGF mRNA ekspresyon seviyesinde dişilerde azalmaya $(\mathrm{p}<0.01)$ neden olurken, erkeklerde artışa neden olmaktadır. Elde edilen sonuçlara göre, testosteron hormonunun yaşlı erkek ve dişi farelerde farklı anjiyogenik etkiye sahip olduğu belirlendi. Ayrıca her iki cinsiyette de gonadektomi operasyonunun VEGF'nin mRNA seviyesinde azalmaya neden olduğu saptandı.

Anahtar sözcükler: Aorta thoracica, fare, testosteron, VEGF, yaşl1lık.

\section{Introduction}

Angiogenesis is a physiological process involving the growth of new blood vessels from pre-existing vessels. Angiogenesis, a normal process in growth and development, is also effective in tumor growth. In absence of angiogenesis, cardiovascular and cerebrovascular diseases may occur. Angiogenic factors, found in a lot of organs and tissues, are made of proteins and stimulate angiogenesis. Some of the latter factors involve vascular endothelial growth factor (VEGF), platelet derived growth factor (PDGF) and fibroblast growth factor (FGF) (14). VEGF, a subfamily of growth factors, is an essential catalyst promoting endothelial cell proliferation, initiating angiogenic sprouting and creating vascular structures. VEGF-A is the most important one in mediating endothelial cell proliferation. VEGFs interact with a set of 
cellular membrane tyrosine-kinase receptors. VEGF-A regulated by androgens is a major mediator of androgen actions on endothelial cell proliferation (2). There are few and limited studies about the effects of testosterone on angiogenesis $(16,17)$. Testosterone has protective effects on formation of cells in the arterial vessels (6). Testosterone has kinetic effects in vessels; in the first stage testosterone is vasodilator, in longer-term exposure, increases the blood pressure and causes renal function abnormalities $(1,8,10,21)$.

In addition to the factors mentioned above, angiogenesis is also affected by the age. Aging is one of the main risk factors for the development of atherosclerosis and, therefore, for coronary artery disease. Age associated remodeling of the vascular wall includes luminal enlargement, intimal and medial thickening, and increased vascular stiffness (22).

There are no articles about how aging and testosterone hormone produce alterations on mammalian aorta. Therefore, the aim of this study was to determine the relationship between the age and the effects of testosterone hormone treatment on morphological alterations and VEGF expression levels in thoracic aorta by histological and molecular techniques.

\section{Materials and Methods}

A total of 15 females, 15 male Swiss albino mice were enrolled. Animals were obtained from Adnan Menderes University, Faculty of Veterinary Medicine, Animal Experimental Unit, Turkey. Ethics committee approval was taken from Adnan Menderes University (with no: B.30.2. ADÜ.0.00.00.00/050.04/2011/098). Mice were grown up to 405 days (13 months +10 days) old in cages under normal conditions $\left(20-24^{\circ} \mathrm{C}\right.$ and $50-60$ $\%$ humidity) and were fed ad libitum with commercially available pelleted feeds. Each of the 3 groups consisted of 10 mice. Out of 10 mice of each group, 5 were males and 5 were females. Among the experimental groups, first group of animals (control) exposed to the same stress sham operations at 12 months (only skin incision and closure). Second experimental group (G) had gonadectomy at the age of 12 months without having testosterone supplementation. Third experimental group had both gonadectomy at the age of 12 months and testosterone supplementation. Third group of animals (GTS) had testosterone supplementation for one month beginning after ten days of post-operative recovery period. For the animals in GTS group, $0.01 \mathrm{cc}$ testosterone $(250 \mathrm{mg} / \mathrm{mL}$ Sustanon $250^{\circledR}$, Organon) was administered by subcutaneous injection as a single dose (7). Mice were anesthetized by intraperitoneal administration of (ip) ketamine $(90 \mathrm{mg} / \mathrm{kg}) /$ xylazine $(10 \mathrm{mg} / \mathrm{kg})$. All animals were euthanized and their blood and tissue (thoracic aorta) samples were taken at the age of 405 days. Testosterone levels in blood samples were measured using ELISA Kit (for mouse testosterone (T), USCN Life Science Inc. ${ }^{\circledR}$ Wuhan) in accordance with the manufacturer's instructions. Thoracic aorta was dissected from the mice and cut in the middle of transversal plane. The first half of aorta was collected for histological examination and the other half was devoted to molecular investigation. Tissue samples were kept in $10 \%$ buffered formalin solution and were embedded in paraffin after routine histological techniques. For each tissue from paraffin blocks of $5 \mu \mathrm{m}$ three serial sections were taken with an interval of $30 \mu \mathrm{m}$. The sections stained with Mallory's trichrome (3). Thickness of intima and media and the inner diameter of thoracic aorta were measured under light microscope. The sections were analyzed and photographed under a light microscope (Leica DMLB) that was equipped with a calibrated digital camera (Leica DC200 CD camera and Q-win Standard imaging analyses program). Histomorphometric analyses were performed at a magnification of x 40-100. Data of thoracic aorta were measured and averaged after the results of 15 different microscopic sites were collected.

For molecular investigation, total RNA extraction from tissue samples was performed using geneJET RNA Purification kit (Fermentas) according to the manufacturer's instructions. Reverse transcription using 2 $\mu \mathrm{g}$ of total RNA, was done with revertAid First Strand cDNA Synthesis kit (Fermentas) containing M-MuLV reverse transcriptase enzyme following manufacturer's instructions. The resulting cDNA was used for real time PCR amplification. Primers were designed to be specific for mouse sequence using web-based QuantiProb design software (www.quiagen.com). The forward primer for VEGF was 5'-GGAGATCCTTCGAGGAGCACTT-3' and reverse primer was 5'-GGCGATTTAGCAGCAGA TATAAGAA-3'. For RNA extraction and PCR procedures of standardization and control the housekeeping transcript (GAPDH) were used. The forward primer for GAPDH was 5'-GAGGGGCCATCCACAGTCTTCT-3' and reverse primer was 5'-GGAGCCAAACGGGTCATCATCTC-3'. Genes were amplified using QuantiTect SYBR PCR Kit $(\mathrm{ABM})$ as defined by Shidaifat et al. (16).

Statistical analysis was used in the SPSS 19.00 software package. Distributions of data were analyzed using Shapiro-Wilk test. Non-parametric distribution the data was checked using the Kruskal-Wallis test. Bonferroni- corrected Mann-Whitney U test was applied as post-hoc test. A $p$-value less than 0.05 were considered significant.

\section{Results}

Testosterone level: Blood testosterone levels were shown in Table 1. The highest level of testosterone was detected in testosterone supplemented female mice, followed by control male group. Among the male mice 
after castration, testosterone levels were decreased by 18.8 fold $(\mathrm{p}<0.01)$ and testosterone replacement increased hormone levels by 13.1 fold among castrated mice $(\mathrm{p}<0.01)$. In female mice testosterone levels were found to be decreased by 2.8 fold in ovariectomized female. After hormone supplementation testosterone levels were increased by 77.2 fold compared to ovariectomized female $(\mathrm{p}<0.001)$. In female mice after testosterone replacement the testosterone levels were increased in GTS group, when compared to control $(\mathrm{p}<0.05)$ and $\mathrm{G}$ groups $(\mathrm{p}<0.001)$.

Table 1. Testosterone levels in male and female groups of mice. Control; sham operated group, G; gonadectomized group, GTS; gonadectomized and testosterone supplemented group.

Tablo 1. Erkek ve dişi fare gruplarında testosteron seviyesi. Kontrol; yalanc1 gonadektomi operasyonu yapılan, G; gonadektomi operasyonu yapılan, GTS; hem gonadektomi hem de testosteron takviyesi yapilan grup.

\begin{tabular}{|l|c|c|}
\hline \multirow{2}{*}{$\begin{array}{l}\text { Animal } \\
\text { groups (N) }\end{array}$} & \multicolumn{2}{|c|}{$\begin{array}{c}\text { Testosterone level nmol/L } \\
\text { (Mean } \pm \text { S.D.) }\end{array}$} \\
\cline { 2 - 3 } & Male & Female \\
\hline Control (10) & $1,517 \pm 1,173^{\text {a }}$ & $0,140 \pm 0,101^{\mathrm{c}}$ \\
\hline G (10) & $0,089 \pm 0,075^{\mathrm{a}, \mathrm{b}}$ & $0,051 \pm 0,064^{\mathrm{d}}$ \\
\hline GTS (10) & $1,051 \pm 0,478^{\mathrm{b}}$ & $3,862 \pm 2,838^{\mathrm{c}, \mathrm{d}}$ \\
\hline
\end{tabular}

a, b; In male mice after castration testosterone levels were decreased $(\mathrm{p}<0.01)$ in $\mathrm{G}$ group of mice. With testosterone replacement increased hormone levels in GTS group of male mice $(\mathrm{p}<0.01),{ }^{\mathrm{c}, \mathrm{d}}$; In female mice after testosterone replacement the testosterone levels were increased in GTS group, to compared to control $(\mathrm{p}<0.05)$ and $\mathrm{G}$ group $(\mathrm{p}<0.001)$.

a, b; Erkek farelerde, kastrasyondan sonra testosteron seviyesi G grup farelerde azalmıştır ( $\mathrm{p}<0.01)$. Testosteron takviyesiyle GTS grup erkek farelerde hormon seviyesi artmıştır $(\mathrm{p}<0.01)$, ${ }^{\mathrm{c}, \mathrm{d}}$; Dişi farelerde, testosteron takviyesinden sonra testosteron seviyesi kontrol $(p<0.05)$ ve $G$ grup $(p<0.001)$ farelerle karşılaştırıldığında GTS grup farelerde artmıştır.
Presence of a correlation between the angiogenic events in aorta tissue and the levels of testosterone was also tested. There were no significant correlations.

Intima: The mean intima thickness of aorta was the highest in $\mathrm{G}$ group male animals whereas the mean intima thickness was the lowest in control male group mice (Table 2). After castration, no significant changes were observed in the intima thickness. Hormone supplementation did not affect the intima thickness in thoracic aorta of castrated animals. In female aorta, the maximum thickness was found in GTS group animals, and the mean intima thickness was the lowest in $\mathrm{G}$ group animals (Table 2). In female aorta, after ovariectomy thickness of the intima decreased slightly but hormone supplementation caused by 1.15 -fold increase $(\mathrm{p}<0.01)$ on intimal thickness in thoracic aorta, compared to ovariectomized female (Figures 1A and B).

Media: Thickness of media in aorta was the highest in $\mathrm{G}$ group male animals. Mean media thickness was the lowest in control male group followed by GTS male group mice (Table 2). Neither castration nor hormone supplementation affected the thickness of media in thoracic aorta of aged mice. In female aorta, the maximum thickness of media was found in control group animals whereas, the mean media thickness was the lowest in GTS group animals (Table 2). Ovariectomy and hormone supplementation did not affect medial thickness of thoracic aorta (Figures 1A and B).

Inner diameter: Inner diameter of GTS groups of both sexes had the largest compared to the other groups. Gonadectomy operation and hormone supplementation did not influence on the inner diameter of thoracic aorta in male. While gonadectomy operation did not affect the inner diameter of thoracic aorta in female, hormone supplementation within the gonadectomized mice caused

Table 2. Intima and media thickness $(\mu \mathrm{m})$, and inner diameter $(\mu \mathrm{m})$ values of thoracic aorta in male and female groups of mice. Control; sham operated group, G; gonadectomized group, GTS; gonadectomized and testosterone supplemented group.

Tablo 2. Erkek ve dişi fare gruplarında aorta thoracica'daki intima, media kalınlıkları $(\mu \mathrm{m})$ ve iç çap ( $\mu \mathrm{m})$ değerleri. Kontrol; yalancı gonadektomi operasyonu yapılan, G; gonadektomi operasyonu yapılan, GTS; hem gonadektomi hem de testosterone takviyesi yapılan grup.

\begin{tabular}{|l|l|l|l|l|}
\hline & Animal groups (N) & $\begin{array}{l}\text { Intima thickness } \\
(\text { Mean } \pm \text { S.D. })\end{array}$ & $\begin{array}{l}\text { Media thickness } \\
(\text { Mean } \pm \text { S.D. })\end{array}$ & $\begin{array}{l}\text { Inner diameter } \\
(\text { Mean } \pm \text { S.D. })\end{array}$ \\
\hline \multirow{4}{*}{ Male } & Control (4) & $2,664 \pm 0,275$ & $63,777 \pm 5,343$ & $621,158 \pm 69,162$ \\
\cline { 2 - 5 } & G (5) & $2,757 \pm 0,145$ & $65,156 \pm 9,404$ & $616,523 \pm 70,801$ \\
\cline { 2 - 5 } & GTS (5) & $2,681 \pm 0,238$ & $63,218 \pm 8,640$ & $624,488 \pm 100,590$ \\
\hline \multirow{3}{*}{ Female } & Control (5) & $2,721 \pm 0,135^{\text {a }}$ & $63,892 \pm 3,006$ & $568,902 \pm 94,214$ \\
\cline { 2 - 5 } & G(5) & $2,537 \pm 0,092^{\text {b }}$ & $63,832 \pm 8,550$ & $568,145 \pm 86,913$ \\
\cline { 2 - 5 } & GTS (5) & $2,918 \pm 0,125^{\text {b }}$ & $61,961 \pm 5,096$ & $621,154 \pm 53,652$ \\
\hline
\end{tabular}

a,b; In female aorta, hormone supplementation caused increase $(\mathrm{p}<0.01)$ on intimal thickness in thoracic aorta, compared to ovariectomized female.

a,b; Dişilerde hormon takviyesi aorta thoracica'nın intima kalınlığında kısırlaştırılmış farelerle karşılaştırıldığında artışa $(p<0.01)$ neden olmuştur. 


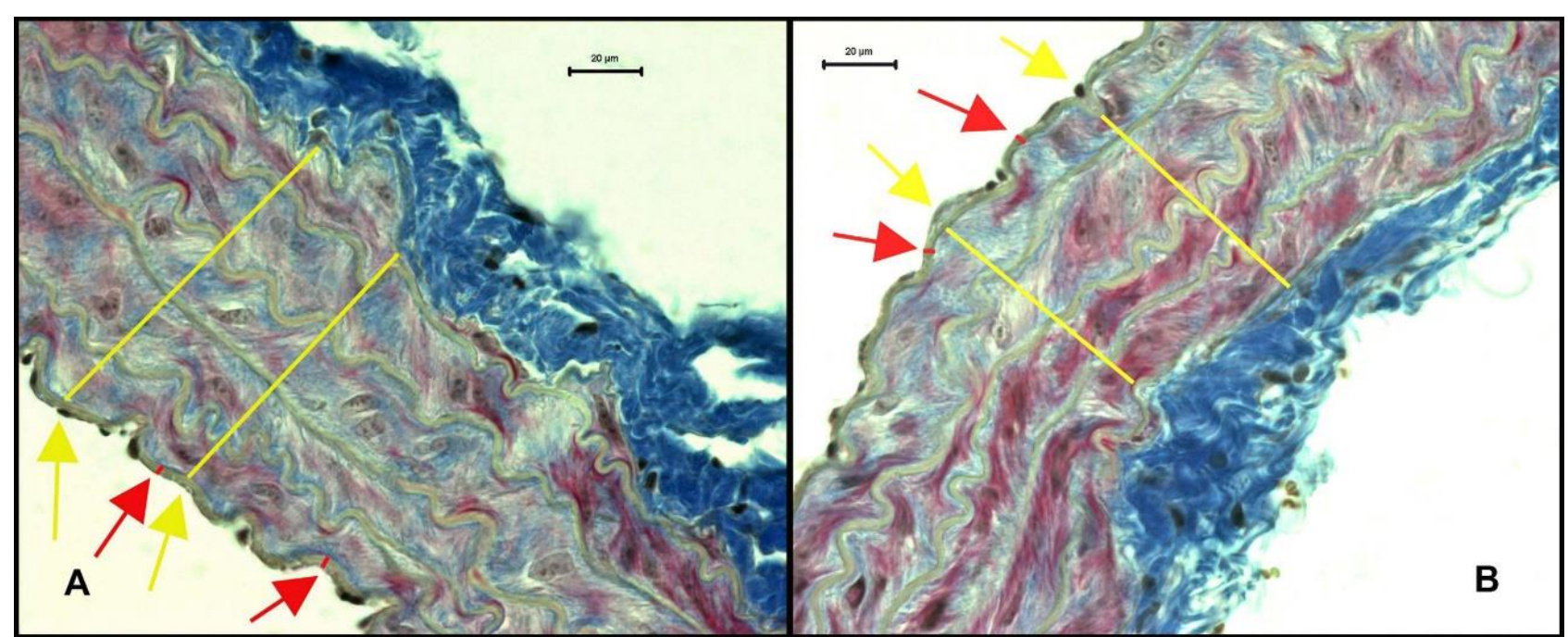

Figure 1. Changes in the thickness of intima and media in thoracic aorta of gonadectomized female mice with and without testosterone replacement. Sections performed triple (Mallory's trichrome method) staining (3). A; gonadectomized group (G), B; gonadectomized and testosterone supplemented group (GTS). Red line: intima, yellow line: media thickness.

Şekil 1. Gonadektomize edilmiş dişi farelerde testosteron takviyesi ile aorta thoracica'nın intima ve media kalınlarındaki değişimler. Kesitler Mallory'nin üçlü boyama metoduyla boyanmıştır (3). A; gonadektomi yapılmış grup (G), B; gonadektomi yapılmış ve testosteron takviyesi almış grup (GTS). Kırmızı çizgi: intima, Sarı çizgi: media kalınlığı.

a slightly increase in diameter by 1.09 fold in female mice. The GTS group had the largest vessel among the groups, besides no statistically significant differences were found in size of the vessels both in male and female mice (Table 2).

Table 3. The VEGF mRNA levels $(\Delta \mathrm{CT})$ of thoracic aorta in male and female groups of mice. Control; sham operated group, G; gonadectomized group, GTS; gonadectomized and testosterone supplemented group.

Tablo 3. Erkek ve dişi fare gruplarında aorta thoracica'daki VEGF mRNA seviyeleri $(\Delta \mathrm{CT})$. Kontrol; yalanc1 gonadektomi operasyonu yapılan, G; gonadektomi operasyonu yapılan, GTS; hem gonadektomi hem de testosteron takviyesi yapılan grup.

\begin{tabular}{|l|l|l|}
\hline & $\begin{array}{l}\text { Animal groups } \\
(\mathrm{N})\end{array}$ & $\begin{array}{l}\text { VEGF }(\Delta \mathrm{CT}) \\
(\text { Mean } \pm \text { S.D. })\end{array}$ \\
\hline \multirow{4}{*}{ Male } & Control (4) & $5,068 \pm 1,130(4)^{\mathrm{a}}$ \\
\cline { 2 - 3 } & G (5) & $1,064 \pm 2,239(5)^{\mathrm{a}}$ \\
\cline { 2 - 3 } & GTS (5) & $2,897 \pm 3,515(4)^{\mathrm{b}}$ \\
\hline \multirow{4}{*}{ Female } & Control (5) & $4,262 \pm 0,518(5)^{\mathrm{c}}$ \\
\cline { 2 - 3 } & G (5) & $0,293 \pm 2,514(5)^{\mathrm{d}}$ \\
\cline { 2 - 3 } & GTS (5) & $-1,721 \pm 0,759(5)^{\mathrm{c}}$ \\
\hline
\end{tabular}

a,b; Amount of VEGF mRNA in aorta tissue were decreased in castrated animals $(\mathrm{p}<0.05)$ compared to control group in male mice, ${ }^{c}$, d. In female aorta VEGF mRNA levels decreased in GTS group compared to control group $(\mathrm{p}<0.01)$.

a,b; Aorta dokusundaki VEGF mRNA miktarı kastre edilmiş erkek farelerde kontrol grubuyla karşılaştırıldığında azalmıştır $(\mathrm{p}<0.05)$, c, d; GTS grup dişilerde aorta'daki VEGF mRNA miktarı kontrol grubuyla karşılaştırıldığında azalmıştır $(\mathrm{p}<0.01)$.

Data of RT PCR: It was determined that the level of VEGF mRNA in both sexes of aorta was the highest in the control group and the lowest in $\mathrm{G}$ group in male and in
GTS group female animals (Table 3). Amount of VEGF mRNA in aorta tissue was decreased by 4.76 fold in castrated animals $(\mathrm{p}<0.05)$ when compared to control group in male mice. In testosterone supplementation group expression levels were increased by 2.72 fold in contrast to $\mathrm{G}$ group in male mice. The increase in GTS group was no significant in comparison to other groups. In female aorta VEGF mRNA levels were decreased by 2.32 folds and by 6.98 folds ( $\mathrm{p}<0.01$ ) for $\mathrm{G}$ and GTS groups, in comparison to the control group, respectively. In GTS group 3.01fold decrease was observed in contrast to $G$ group in expression level.

\section{Discussion and Conclusion}

Recently, longitudinal epidemiological studies have found low testosterone levels to be associated with an increased risk of all-cause and cardiovascular mortality. Testosterone has direct effects on vascular tone causing vasodilatation, an increase in coronary blood flow (12). An association of low testosterone levels with decreased flow-mediated dilation, which is a measurable marker of endothelial dysfunction causing atherosclerosis, has been reported. It was also reported that serum testosterone concentration inversely and independently correlates with the presence of aortic calcified plaques and the progression of aortic atherosclerosis in human (20) and in rabbit (11). Various animal models using rodents, rabbits, dogs, and swine have also demonstrated an acute dilation to androgen in both in vivo and in vitro studies (13). Testosterone replacement significantly delayed plaque formation in castrated rabbits (11). High dose intravenous testosterone increased flow mediated dilation in men with 
coronary artery diseases. (13). In the present study, although gonadectomy operation and hormone supplementation did not affect the inner diameter of thoracic aorta in males, hormone supplementation to gonadectomized mice caused slight increase in diameter by 1.09 folds in female mice. The GTS group had the largest vessels among the groups, whereas no statistically significant differences were found in the sizes of the vessels both in male and female mice.

An inverse correlation between plasma testosterone levels and carotid intima-media thickness (IMT) was reported in men. Carotid IMT has been widely used as a surrogate marker of atherosclerosis and a number of IMT determinants have been identified. Several cross-sectional and longitudinal studies possessed an inverse association between testosterone levels and carotid IMT. In elderly men, the low plasma testosterone is associated with elevated carotid intima-media thickness only in those with low-grade inflammation (18). Testosterone replacement therapy contributes to reduction of carotid intima media thickness. Testosterone may have the potential to decrease cardiovascular disease risk in men with androgen deficiency (15). It was determined that the low total testosterone levels may be considered a significant marker of atherosclerosis in patients with idiopathic hypogonadotropic hypogonadism and that the androgen replacement therapy significantly reduces atherosclerotic risk markers in these patients after 6 months (4). In the present study after gonadectomy operation in aged mice while no significant changes were observed in intima and media thickness of aorta in male, only thickness of intima decreased slightly in female aorta. Hormone supplementation did not affect the intima and media thickness in thoracic aorta of castrated animals, whereas in female hormone supplementation caused by 1.15 fold increase $(\mathrm{p}<0.01)$ on intimal thickness and slightly decreased the media thickness in thoracic aorta, compared to ovariectomized female.

Previous studies showed that androgens stimulate erythropoietin production via VEGF in cell culture and endothelial stem cells. In the absence of these hormones as mean of castration, angiogenesis is downward (17). According to Sordello et al. (19), testosterone caused an increase in transcription and biological activity of VEGF in human prostate cell culture. In vivo, a transient increase in the weight of ventral lobes of the prostate gland and 7fold increase in specific activity of VEGF belong to prostate in testosterone injected rats were observed (19). After castration a decrease was observed in both translation and transcription levels of VEGF of the prostate gland of the dog (16). However, Sieveking et al. (17), observed difference in the effect of testosterone hormone in male and female, an increase was observed in males in the angiogenesis depend on VEGF but no effect in females. Cai et al. (2) demonstrated that androgens [dihydrotestosterone (DHT) and testosterone], produced a time- and dose-dependent induction of cell proliferation in primary human aortic endothelial cells (HAECs) and DHT induced VEGF gene expression in a dose- and timedependent manner. In the present study, amount of VEGF mRNA in aorta tissue were 4.76 fold low in castrated animals $(\mathrm{p}<0.05)$ compared to control group, by testosterone supplementation increased by 2.72 fold in comparison to $\mathrm{G}$ group in male mice. In female, VEGF mRNA after gonadectomy was reduced by 2.32 fold, by hormone replacement even more $6.98(\mathrm{p}<0.001)$ fold compared to control group. In GTS group 3.01 fold decreased were observed when compared to $G$ group in expression level.

Androgens have different effects of angiogenesis by gender. In vitro studies showed that the androgens stimulate angiogenic phenomena in male, but not in females. In addition, in vivo studies shown that the endogenous androgens regulate angiogenesis in males, but not in females (17). Jesmin et al. (2003) performed ovariectomie operation after 44 weeks to female rats. Afterwards it was observed that the vessel density, VEGF and receptors of VEGF levels were decreased in brain (frontal cortex) (9). Hak et al. (5) were studied the longterm effects of androgen treatment on atherosclerosis in postmenopausal women. Intramuscular hormone therapy used for 1 year or longer was reported by 25 women. In almost half of these women, severe atherosclerosis of the aorta was present $(n=11)$, whereas in women without hormone use, severe atherosclerosis of the aorta was detected in less than $20 \%$. In the present study alterations in inner diameter of thoracic aorta in male and female following gonadectomy and hormone supplementation were similar. Taking into account intima and media thickness in aorta, there were no changes in male by gonadectomy and hormone supplementation. But in female after gonadectomy thickness of intima decreased slightly, with hormone supplementation presenting increase $(p<0.01)$ on intimal thickness. There were no changes on the media thickness in female thoracic aorta. Amount of VEGF mRNA in aorta tissue after gonadectomy was reduced in both sexes ( $p<0.05$ in male), by hormone replacement that was increased in male but decreased $(\mathrm{p}<0.01)$ in female.

Available evidence suggested that, gonadectomy and testosterone supplementation caused no alterations in intima and media of thoracic aorta in the aged male mice in the present study. In females, while gonadectomy caused a decrease on intimal thickness and testosterone supplementation to gonadectomized mice caused an increase on intimal thickness of thoracic aorta. While gonadectomy operation and hormone supplementation did not affect the inner diameter of thoracic aorta in males, 
hormone supplementation to gonadectomized mice caused slight increase in diameter in female mice. In addition, after gonadectomy there was a decrease in the level of VEGF mRNA in both sexes and decrease was even more in females but increase in males after hormone replacement. Decreased testosterone levels in aged male mice have an important negative effect on VEGF mRNA levels. Interestingly, testosterone replacement caused a decrease in the expression of VEGF of aorta in gonadectomized females but in males caused slight increase.

\section{References}

1. Alexandersen P, Christiansen C (2004): The aging male: Testosterone deficiency and testosterone replacement. An up-date. Atherosclerosis, 173, 157-169.

2. Cai J, Hong Y, Weng C, et al. (2011): Androgen stimulates endothelial cell proliferation via an androgen receptor/VEGF/cyclin A-mediated mechanism. Am J Physiol Heart Circ Physiol, 300, 1210-1221.

3. Crossman OA (1937): Modification of Mallory's connective tissue stain with a discussion of the principles involved. Anat Rec, 69, 31.

4. Doğan BA, Karakılıç E, Tuna MM, et al. (2015): Effect of androgen replacement therapy on atherosclerotic risk markers in young-to-middle-aged men with idiopathic hypogonadotropic hypogonadism. Clin Endocrinol, 82, 422-428.

5. Hak AE, Westendorp IC, Pols HA, et al. (2007): Highdose testosterone is associated with atherosclerosis in postmenopausal women. Maturitas, 56, 153-160.

6. Hanke H, Lenz C, Hess B, et al. (2001): Effect of testosterone on plaque development and androgen receptor expression in the arterial vessel wall. Circulation, 103, 1382-1385.

7. Hsu YJ, Dimke H, Schoeber JP, et al. (2010): Testosterone increases urinary calcium excretion and inhibits expression of renal calcium transport proteins. Kidney Int, 77, 601-608.

8. Iliescu R, Reckelhoff JF (2006): Testosterone and vascular reactivity. Clin Sci, 111, 251-252.

9. Jesmin S, Hattori Y, Sakuma I, et al. (2003): Estrogen deprivation and replacement modulate cerebral capillary density with vascular expression of angiogenic molecules in middle-aged female rats. J Cereb Blood Flow Metab, 23, 181-189.

10. Kearney ML, Hurn FPD (2004): Testosterone as a modulator of vascular behavior. Biol Res Nurs, 5, 276-285.

11. Li S, Guo Y, Zhu P, Yang T (2013): Role of $O x-L D L / L O X-$ $1 / N F-\kappa B$ signaling pathway in regulation of atherosclerotic plaque growth by testosterone in male rabbits. Vascul Pharmacol, 59, 131-137.
12. Mathur A, Malkin C, Saeed B, et al. (2009): Long-term benefits of testosterone replacement therapy on angina threshold and atheroma in men. Eur J Endocrinol, 161, 443449.

13. O'Connor EK, Ivey JR, Bowles DK (2012): Differential effects of androgens on coronary blood flow regulation and arteriolar diameter in intact and castrated swine. Biol Sex Differ, 3, 10.

14. Otrock ZK, Mahfouz RAR, Makarem JA, et al. (2007): Understanding the biology of angiogenesis: Review of the most important molecular mechanisms. Blood Cells Mol Dis, 39, 212-220.

15. Saad F (2012): Androgen therapy in men with testosterone deficiency: Can testosterone reduce the risk of cardiovascular disease? Diabetes Metab Res Rev, 28, 5259.

16. Shidaifat F, Gharaibeh M, Bani-Ismail Z (2007): Effect of castration on extracellular matrix remodeling and angiogenesis of the prostate gland. Endocr J, 54, 521-529.

17. Sieveking DP, Lim P, Chow RWY, et al. (2010): A sexspecific role for androgens in angiogenesis. J Exp Med, 207, 345-352.

18. Soisson V, Brailly-Tabard S, Empana JP, et al. (2012): Low plasma testosterone and elevated carotid intima-media thickness: Importance of low-grade inflammation in elderly men. Atherosclerosis, 223, 244-249.

19. Sordello S, Bertrand N, Plouet J (1998): Vascular endothelial growth factor is up-regulated in vitro and in vivo by androgens. Biochem Biophys Res Commun, 251, 287-290.

20. Tsujimura A, Yamamoto R, Okuda H, et al. (2012): Low serum free testosterone level is associated with carotid intima-media thickness in middle-aged Japanese men. Endocr J, 59, 809-815.

21. Wang W, Chao S, Xian W (2002): Alteration of vascular response to norepinephrine, calcitonin gene-related peptide, and acetylcholine in orchidectomized rats. Acta Pharm Sinic, 23, 985-990.

22. Yıldız O (2007): Vascular smooth muscle and endothelial functions in aging. Ann N Y Acad Sci, 1100, 353-360.

Geliş tarihi: 05.01.2016 / Kabul tarihi: 12.04.2017
Address for correspondence:
Prof. Dr. İlknur DABANOĞLU
Adnan Menderes University,
Faculty of Veterinary Medicine,
Department of Anatomy
Işıklı Köyü 09016 Aydın, Turkey.
Tel: + 90256247 0700-242
e-mail:dabanf@yahoo.com 